\title{
Gambaran Kadar Asam Urat Serum pada Remaja dengan Overweight dan Obesitas
}

\author{
${ }^{1}$ Inggriano G. V. Matialu \\ ${ }^{2}$ Murniati Tiho \\ ${ }^{2}$ Youla A. Assa
}

\author{
${ }^{1}$ Program Studi Pendidikan Dokter Fakultas Kedokteran Universitas Sam Ratulangi Manado \\ ${ }^{2}$ Bagian Biokimia Fakultas Kedokteran Universitas Sam Ratulangi Manado \\ Email: matialuinggrid@gmail.com
}

\begin{abstract}
Nowadays, obesity has become a serious problem world-wide. Obesity can cause the emergence of various kinds of diseases; one of them is hyperuricemia. This condition could found in obese adult as well as in obese adolescence. This study was aimed to obtain the serum uric acid level profile among high school students with overweight and obesity. This was a descriptive study with a cross sectional design. Subjects were grade X-XI students of SMA Negeri 2 Bitung with body mass index (BMI) $>85$. There were 23 students involved in this study. The results showed that $60.87 \%$ subjects had hyperuricemia. Conclusion: Most adolescence with obesity tend to have uric acid level above normal value.
\end{abstract}

Keywords: adolescence, obesity, hyperuricemia, serum uric acid

\begin{abstract}
Abstrak: Obesitas saat ini sudah menjadi sebuah permasalahan serius bagi dunia. Obesitas dapat menyebabkan timbulnya berbagai penyakit seperti hiperurisemia. Masalah hiperurisemia tidak hanya terjadi pada orang dewasa yang obes tetapi juga dapat menyerang remaja yang obes. Penelitian ini bertujuan mengetahui gambaran kadar asam urat serum pada siswa yang mengalami overweight maupun obesitas. Jenis penelitian ini ialah deskriptif dengan desain potong lintang. Subjek penelitian ialah siswa kelas X-XI SMA Negeri 2 Bitung yang memiliki IMT diatas persentil 85 sebanyak 23 siswa. Hasil penelitian menunjukkan bahwa sebanyak $60,87 \%$ siswa mengalami hiperurisemia. Simpulan: Remaja dengan obesitas cenderung memiliki kadar asam urat di atas normal.
\end{abstract}

Kata kunci: remaja, obesitas, hiperurisemia, asam urat serum

Dalam beberapa dekade terakhir terjadi peningkatan yang cukup bermakna terhadap konsumsi makanan cepat saji, minuman bersoda, dan permen. Pada waktu yang sama, pola aktivitas fisik pada remaja telah berubah dimana terjadi peningkatan jumlah waktu yang dihabiskan untuk menonton televisi, bermain video game dan internet, dibanding kesempatan untuk melakukan aktivitas fisik baik di sekolah maupun di masyarakat. Hal ini mengakibatkan peningkatan kejadian berat badan berlebih.

Berat badan yang melebihi normal disebut sebagai overweight dan obesitas. ${ }^{2}$
Obesitas merupakan keadaan yang diakibatkan oleh asupan makanan yang tidak seimbang dalam waktu yang lama, dimana energi yang masuk lebih besar daripada energi yang dikeluarkan. ${ }^{3}$

Menurut data dari Central for Disease Control and Prevention (CDC), dalam satu dekade terakhir sebanyak kira-kira 12,7 juta $(17 \%)$ anak dan remaja mengalami obesitas. Pada tahun 2011-2012, sebanyak $20,25 \%$ anak berusia antara 12 sampai 19 tahun mengalami obesitas dan jika dibandingkan dengan kelompok usia yang lain merupakan yang paling tinggi. ${ }^{4}$ Dalam 
survei yang diselenggarakan oleh Riskesdas pada tahun 2010 dan 2013 di Indonesia, prevalensi untuk remaja usia 1618 tahun yang gemuk naik dari $1,4 \%$ menjadi $7,3 \% .^{5}$

Salah satu akibat dari obesitas ialah meningkatnya kadar asam urat. Peningkatan kadar asam urat serum disebut juga dengan hiperurisemia. Berdasarkan peneliian yang telah dilakukan pada tikus, telah dibuktikan bahwa hiperurisemia juga dapat mengakibatkan peningkatan tekanan darah sistemik, disfungsi ginjal, proteinuria, dan penyakit vaskular. Bukti yang ada juga mendukung pendapat bahwa hiperurisemia dapat menjadi mekanisme kunci untuk aktivasi dari renin-angiotensin dan cyclooxygenase- 2 (COX-2) dalam penyakit ginjal secara progresif. ${ }^{6}$

Beberapa penelitian menunjukkan adanya keterkaitan antara obesitas dan kadar asam urat serum. ${ }^{7}$ Asam urat merupakan hasil katabolisme dari nukleotida purin. Meskipun telah difiltrasi oleh glomerulus dan disekresikan oleh tubulus distal ke dalam urin, sebagian besar asam urat diabsorpsi kembali ke dalam tubulus proksimal dan digunakan kembali. Asam urat relatif tidak larut di dalam plasma dan pada konsentrasi tinggi dapat didepositkan ke dalam sendi dan jaringan sehingga menyebabkan peradangan. ${ }^{8}$

Saat ini jumlah penderita hiperurisemia dan gout telah menunjukkan peningkatan yang cukup pesat di seluruh dunia. Di Jepang dilaporkan prevalensi hiperurisemia pada laki-laki dewasa berkisar antara 20$25 \%$ dan terus mengalami peningkatan selama beberapa tahun terakhir. ${ }^{9}$ Menurut penelitian potong lintang yang diselenggarakan di Qingdao, China, dari 2438 orang (1535 perempuan dan 903 laki-laki), sebanyak $25,3 \%$ terkena hiperurisemia dan $0,36 \%$ terkena gout. Kasus ini lebih banyak terjadi pada laki-laki yaitu sebanyak $32,1 \%$ daripada perempuan yang hanya berkisar $21,8 \%{ }^{10}$

Di Indonesia, epidemiologi hiperurisemia pada remaja masih belum diketahui dengan pasti, namun dari beberapa data hasil penelitian seperti di Sinjai (Sulawesi
Selatan) didapatkan angka kejadian hiperurisemia $10 \%$ pada pria dan $4 \%$ pada wanita. Di Bandungan (Jawa Tengah) didapatkan angka kejadian hiperurisemia pada pria $24,3 \%$ dan wanita $11,7 \%$. Di Minahasa diperoleh angka kejadian hiperurisemia $34,30 \%$ pada pria dan $23,31 \%$ pada wanita usia dewasa muda. ${ }^{11}$

Penelitian ini bertujuan untuk mengetahui gambaran kadar asam urat serum pada remaja yang tergolong overweight dan obesitas.

\section{METODE PENELITIAN}

Jenis penelitian ini ialah deskriptif dengan desain potong lintang. Penelitian ini berlangsung mulai dari September 2015 sampai Februari 2016. Pemilihan sampel dilakukan di SMA N 2 Bitung dan pemeriksaan sampel darah dilakukan di laboratorium Prodia. Populasi target penelitian mencakup remaja obesitas dan overweight dengan persentil $\geq 85$, berusia 13-16 tahun. Populasi terjangkau pada penelitian ini merupakan remaja obes dan overweight di SMA N 2 Bitung yang aktif sekolah selama bulan Januari 2016. Responden penelitian menggunakan seluruh populasi yang memenuhi kriteria inklusi dan eksklusi.

\section{HASIL PENELITIAN}

Responden penelitian ini merupakan 23 orang remaja yang bersekolah di SMA N 2 Bitung dengan IMT $\geq 23 \mathrm{~m} / \mathrm{kg}^{2}$ yang memenuhi kriteria inklusi dan eksklusi dan telah bersedia untuk dilakukan penelitian dengan mengisi informed consent.

Jumlah responden penelitian yang tersedia ialah sebanyak 23 orang yang terdiri dari 12 orang berjenis kelamin lakilaki dan 11 orang berjenis kelamin perempuan. Berdasarkan jenis kelamin terdapat 4 orang $(17,39 \%)$ mengalami overweight yaitu 3 orang laki-laki dan 1 orang perempuan dan sebanyak 19 orang $(82,61 \%)$ mengalami obesitas yaitu 9 orang laki-laki dan 10 orang perempuan. (Tabel 1)

Berdasarkan hasil pemeriksaan laboratorium, sebanyak 14 orang $(60,87 \%)$ memiliki kadar asam urat di atas normal 
dan 9 orang $(39,13 \%)$ memiliki kadar asam urat normal. Empat belas orang yang mengalami hiperurisemia tersebut terdiri dari 2 orang yang mengalami overweight dan 12 orang yang lain mengalami obesitas sedangkan untuk 9 orang yang memiliki kadar asam urat normal terdiri dari 2 orang yang mengalami overweight dan 7 orang yang lain obesitas (Tabel 2).

Tabel 1. Status IMT terhadap jenis kelamin

\begin{tabular}{lccc}
\hline \multicolumn{1}{c}{ Status } & $\begin{array}{c}\text { Laki- } \\
\text { laki }\end{array}$ & Perempuan & $(\boldsymbol{\%})$ \\
\hline Over-weight & 3 & 1 & 17,39 \\
Obesitas & 9 & 10 & 82,61 \\
\hline
\end{tabular}

Tabel 2. Status jenis kelamin terhadap kadar asam urat serum

\begin{tabular}{cccc}
\hline Status & $\begin{array}{c}\text { Laki- } \\
\text { laki }\end{array}$ & Perempuan & $\mathbf{( \% )}$ \\
\hline Normal & 4 & 5 & 39,1 \\
Hiperurisemia & 8 & 6 & 60,8 \\
\hline
\end{tabular}

Sesuai dengan data yang telah dirampungkan, sebanyak 8 orang $(66,67 \%)$ laki-laki memiliki kadar asam urat yang tinggi dan 4 orang $(33,33 \%)$ sisanya memiliki kadar asam urat normal. Pada responden berjenis kelamin perempuan, sebanyak 6 orang $(54,54 \%)$ memiliki kadar asam urat yang tinggi dan 5 orang $(45,45 \%)$ yang lain memiliki kadar asam urat normal.

\section{BAHASAN}

Berdasarkan hasil penelitian ini didapatkan bahwa responden yang memiliki kadar asam urat serum yang tinggi lebih banyak terjadi pada laki-laki yaitu sebanyak 8 orang dibandingkan dengan perempuan yang hanya berjumlah 6 orang. Secara klinis, hiperurisemia memang lebih banyak pada laki-laki dibandingkan perempuan. Efek urikosurik yang diberikan oleh estrogen bekerja untuk meningkatkan pembuangan asam urat ke dalam urin cukup berpengaruh pada kadar asam urat dalam darah. ${ }^{13}$

Berdasarkan data penelitian dapat dilihat dari seluruh responden, hanya 9 orang $(39,13 \%)$ yang memiliki kadar asam urat serum normal. Hal ini sejalan dengan penelitian Saag dan $\mathrm{Choi}^{13}$ yang melaporkan bahwa orang yang mengalami overweight dan obesitas cenderung memiliki kadar asam urat tinggi. Hiperurisemia pada overweight dan obesitas terjadi melalui resistensi hormon insulin. Berbagai penelitian telah mengungkapkan bahwa resistensi insulin ternyata berbanding terbalik dengan clearance asam urat urin 24 jam. Oleh karena itu, terjadinya penurunan ekskresi asam urat pada ginjal dapat menjelaskan bahwa pada manusia, insulin ternyata dapat meningkatkan reabsorpsi tubulus ginjal terhadap asam urat. ${ }^{14}$

Konsumsi purin yang berlebihan melalui makanan juga dapat menjadi salah satu penyebab hiperurisemia pada anak dengan overweight maupun obesitas. Kecenderungan anak yang memiliki berat badan lebih untuk mengonsumsi makanan yang kaya akan purin seperti daging dan ikan juga merupakan salah satu faktor penyebab hiperurisemia. ${ }^{15}$

Penelitian ini juga menjelaskan bahwa tidak semua anak dengan berat badan lebih mengalami peningkatan kadar asam urat serum. Selain obesitas, peningkatan kadar asam urat serum juga dipengaruhi oleh beberapa faktor lainnya. Sebanyak 9 orang responden $(39,13 \%)$ memiliki kadar asam urat normal. Usia juga berperan cukup penting terhadap ekskresi asam urat terlebih khusus pada anak perempuan. ${ }^{16}$

Limitasi penelitian ini ialah jumlah responden penelitian yang hanya mencapai $76,7 \%$ dari seluruh populasi yang dapat memengaruhi sebaran data.

\section{SIMPULAN}

Berdasarkan hasil penelitian dapat disimpulkan bahwa sebagian besar remaja dengan overweight dan obesitas cenderung mengalami hiperurisemia.

\section{SARAN}

1. Perlu dilakukan penyuluhan kepada siswa mengenai pola hidup sehat dengan mengatur pola makan yang sehat dan seimbang serta berolah raga secara 
teratur.

2. Perlu mengurangi berat badan agar tidak terjadi hiperurisemia.

\section{DAFTAR PUSTAKA}

1. Jansen I, Katzmarzyk PT, Boyce WF, King MA, Pickett W. Overweight and obesity in Canadian adolescents and their associations with dietary habits and physical activity patterns. J Adolesc Health. 2004;35:360-67.

2. CDC. Defining adult overweight and obesity. 2012 April 27 [cited 2016 Feb 2]. Available from: http://www.cdc.gov/ obesity/adult/defining.html

3. Canoy D, Bundred P. Obesity in children. Clinical Evidence. 2011;4:325-44

4. CDC. Childhood obesity facts. 2015 June 9 [cited 2016 Feb 2]. Available from: www.cdc.gov/obesity/data/childhood.ht $\mathrm{ml}$

5. [RISKESDAS] Riset Kesehatan Dasar. 2013. Jakarta: Badan Penelitian dan Pengembangan Kesehatan, Departemen Kesehatan, Republik Indonesia.

6. Kang DH, Nakagawa T. Uric acid and chronic renal disease: possible implication of hyperuricemia on progression of renal disease. Semin Nephrol. 2005;(1):43-9.

7. Akram M, Asif HM, Udmanghani K, Akhtar N, Jabeen Q, Madni A, et al. Obesity and the risk of hyperuricemia in Gadap Town, Karachi. African J Biotechnol 2011;10(6):996-8

8. Bishop ML, Fody EP, Schoeff LE. In: Goucher J, editor. Clinical Chemistry (6th ed). Philladelphia: LWW, 2010; p.
270.

9. Hakoda M. Epidemiology of hyperuricemia and gout in Japan. Nihon Rinsho. 2008;66(4):647-52

10. Nan H, Qiao Q, Dong Y, Gao W, Tang B, Qian R, et al. The prevalence of hyperuricemia in a population of the coastal city of Qingdao, China. J Rheumatol. 2006;33(7):1346-50.

11. Manampiring AE, Bodhy W. Prevalensi hiperurisemia pada remaja obese di kota tomohon. 2012 Jul 08 [cited 2015 Oct 26]. Available from: http://repo. unsrat.ac.id/id/eprint/251

12. Saag KG, Choi H. Epidemiology, risk factors and lifestyles modification for Gout. Arthritis Res Ther. 2006; 8(Suppl1):S2.

13. Sedagath S, Hoorn EJ, van Rooij FJA, Hofman A, Franco OH, Witteman JCM, et al. Serum uric acid and chronic kidney disease: The role of hypertension. PLoS ONE. 2013;8(11): e76827.

14. Pacifico L, Cantisani V, Anania C, Bonaiuto E, Martino F, Pascone R , et al. Serum uric acid and its association with metabolic syndrome and carotid atherosclerosis in obese children. Eur J Endocrinol. 2009; 160(1):45-52.

15. DeBoer MD, Dong L, Gurka MJ. Racial/ethnic and gender differences in the relationship between uric acid and metabolic syndrome in adolescents: an analysis of NHANES 1999-2006. Metabolism. 2012; 61(4): 554-61. 